\title{
Evaluation of Gastric Anti-ulcer Activity in a Hydro- ethanolic Extract from Kielmeyera coriacea
}

\author{
Yara Cavalcante Fortes Goulart, Vania Ramos Sela, Simoni Obici, Juliana Vanessa \\ Colombo Martins, Fernanda Otobone, Diogenes Aparicio Cortez and Elisabeth Aparecida \\ Audi $^{*}$ \\ Departamento de Farmácia e Farmacologia; Universidade Estadual de Maringá; Av. Colombo, 5790; 87020-900; \\ eaaudi@uem.br; Maringá - PR - Brazil
}

\begin{abstract}
The antiulcer activity of a hydro-ethanolic extract prepared from the stems of Kielmeyera coriacea Mart. (Guttiferae) was evaluated in rats employing the ethanol-acid, acute stress and Indomethacin models to induce

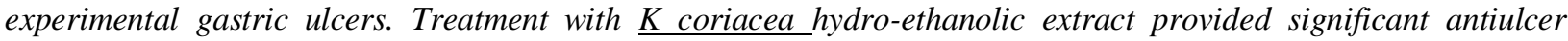
protection in the ethanol-acid and Indomethacin models, but not in the acute stress model. These results suggested

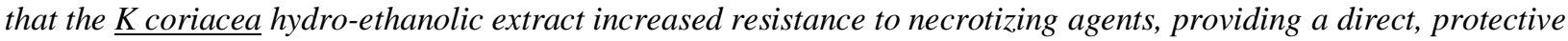
effect on the gastric mucosa.
\end{abstract}

Key words: Acute stress, anti-ulcer activity, ethanol-acid, Indomethacin, Kielmeyera coriacea Mart. (Guttiferae)

\section{INTRODUCTION}

Kielmeyera coriacea Mart. (Guttiferae) is a plant species typically found among the Brazilian cerrado vegetation, and is popularly known as the "pau santo". A decoction from the stems is traditionally used to treat various tropical diseases, including schistosomasis, leishmaniasis, malaria and fungal and bacterial infections (Alves et al, 2000; Ferri, 1969). Xanthones, triterpenes and biphenyl derivatives have been isolated from this plant, and exhibited antifungal activity against Cladosporium cucumerinum and Candida albicans (Cortez et al., 1998). A hydro-ethanolic extract of $K$ coriacea leaves, when administered chronically by gavage, exhibited a notable anxiolytic effect in rats submitted to the elevated plus maze test (Audi et al., 2002). Despite these reports, knowledge of the pharmacological properties of $K$ coriacea is limited, and screening studies are necessary to reveal the medicinal properties of the plant.

Recently, widespread effort have been launched to identify novel anti-ulcer drugs from natural resources. A number of models are available in which to test substances for their anti-ulcer effects. Here, we report on the effect of a hydroethanolic extract from $K$ coriacea stems on gastric lesion induced in different animal models employing necrotizing or stressor agents.

\section{MATERIALS AND METHODS}

\section{Plant material}

$K$ coriacea was collected near Mogi-Guaçu (São Paulo, Brazil) in July, 1999. A voucher specimen (\#SP298463) was deposited with the Herbarium of

Author for correspondence 
the State Botanical Institute, São Paulo, Brazil, and the species identification was performed by $\mathrm{Dr}$ Maria Claudia Young from the same institution.

\section{Extract Preparation}

The stems of $K$ coriacea Mart were crushed and powdered using a grinding mill, a standardized extract being prepared by maceration. The extract was concentrated by evaporation to $10 \%$ of its volume and was then lyophilized. Each $100 \mathrm{~g}$ of powdered stem yielded $17 \mathrm{~g}$ of lyophilized extract. The active solution was prepared by dissolving the lyophilized extract in saline $(0.9 \% \mathrm{NaCl})$. The doses employed ranged from 30 to $120 \mathrm{mg} / \mathrm{kg}$, applied in rats.

\section{Animals}

Male, Wistar rats (200-250 g) provided by the Animal Housing, Facility of Maringá State University were housed in polyethylene-walled cages in groups of five, with food and water $a d$ libitum. The animals were kept on a $12 \mathrm{~h}$ light: 12 $\mathrm{h}$ dark regime (lights on from 7:00 $\mathrm{h}$ to 19:00 $\mathrm{h}$ ) at $23{ }^{\circ} \mathrm{C}$ prior to the experiments.

\section{Treatments}

Doses of 30, 60 or $120 \mathrm{mg} / \mathrm{kg}$ of $K$ coriacea extract were prepared as aqueous suspensions. Cimetidine $(32 \mathrm{mg} / \mathrm{kg})$ and $0.9 \% \mathrm{NaCl}$ were used as the reference drug and control vehicle, respectively. All treatments were administered orally (gavage), $30 \mathrm{~min}$ before the procedures.

\section{Reagents}

The following drugs were used: Cimetidine (Galena), Indomethacin (Sigma), $\mathrm{HCl}$ (Synth).

\section{Procedure to induce acute, gastric, mucosal lesions}

The rats were deprived of food for $24 \mathrm{~h}$, although water was allowed. Immediately after each procedure, the animals were killed and their stomachs removed, opened, and the inner lining examined. The gastric lesions were counted, and an ulcerative index (UI) was calculated for each animal as follows:

$$
\mathrm{UI}=(\mathrm{n} \text { lesion } \mathrm{I})+(\mathrm{n} \text { lesion II }) 2+(\text { n lesion III }) 3
$$

Where:

$\mathrm{I}=$ presence of edema, hyperemia and single, submucosal, punctiform hemorrages (petechiae);
II = presence of submucosal, hemorrhagic lesions with small erosions;

III = presence of deep ulcer with erosions and invasive lesions (Szelenyl and Thiemer, 1978).

\section{Ethanol-acid induced ulcer}

The extract of $K$ coriacea in different doses, Cimetidine or $0.9 \% \mathrm{NaCl}$ were administered to rats $30 \mathrm{~min}$ before ethanol-acid $(25 \mathrm{mg} / \mathrm{kg})$ treatment $(0.3 \mathrm{M} \mathrm{HCl} \mathrm{in} 60 \%$ ethanol). All treatments were made by gavage. After $1 \mathrm{~h}$, the animals were killed and the gastric lesions were counted (Mizui and Douteuchi, 1983).

\section{Acute stress-induced ulcer}

Acute, gastric lesions were induced by stress according to the model of Nagura (1972), modified by Bacchi (1988). After oral administration of $0.9 \% \mathrm{NaCl}$, Cimetidine and different doses of $K$ coriacea extract, each rat was immobilized in a cylindrical cage and vertically immersed in water to the level of the xiphoid process for $17 \mathrm{~h}$ at $23^{\circ}-25^{\circ} \mathrm{C}$. After this, the animals were immediately killed, their stomachs removed, and the gastric lesions were counted.

\section{Indomethacin-induced ulcer}

Indomethacin $(20 \mathrm{mg} / \mathrm{kg})$ was administered subcutaneously to unanesthetized rats, following the method of Aguwa and Mittal (1981). The animals were killed $7 \mathrm{~h}$ later to calculate the ulcerative index. $K$ coriacea extract, Cimetidine or $0.9 \% \mathrm{NaCl}$ were administered $30 \mathrm{~min}$ before Indomethacin treatment.

\section{Acute toxicity}

Acute toxicity studies of $K$ coriacea extract were performed on mice, and the lethal dose was estimated using the method described by Miller and Tainter (1944). Increasing doses of extract were individually administered to groups of 10 animals which were observed daily for 7 days.

\section{Statistical Analysis}

The results are expressed as the mean \pm SEM for each group. Statistical differences were evaluated using a one-way analysis of variance (ANOVA) followed by Dunnett's post-hoc test. Differences were considered to be statistically significant at $\mathrm{P} \leq 0.05$. 


\section{RESULTS}

Gastric mucosal damage, induced using the stress model was not affected by different doses of $K$ coriacea extract $(\mathrm{F}(4,25)=4.79, \mathrm{p}=0.0052)($ Fig 1$)$. Cimetidine $(32 \mathrm{mg} / \mathrm{kg})$, the reference drug, significantly reduced the ulcerative index in all three models of gastric mucosal lesion.

Gastric mucosal lesions, induced using ethanolacid were significantly reduced by the 30 - and $120-\mathrm{mg} / \mathrm{kg}$ doses of extract (Fig 2),
$(\mathrm{F}(4,31)=9.182, \quad \mathrm{p}<0.0001) \quad$ compared to the control group. Gastric lesions induced by Indomethacin (Fig 3) were significantly reduced only by the $30-\mathrm{mg} / \mathrm{kg}$ dose of extract $(\mathrm{F}(4,25)=8.746, \quad \mathrm{p}<0.0001)$ compared to the control group. Administration of $K$ coriacea extract in doses up to $1200 \mathrm{mg} / \mathrm{kg}$ produced no signs of toxicity in mice (data not shown).

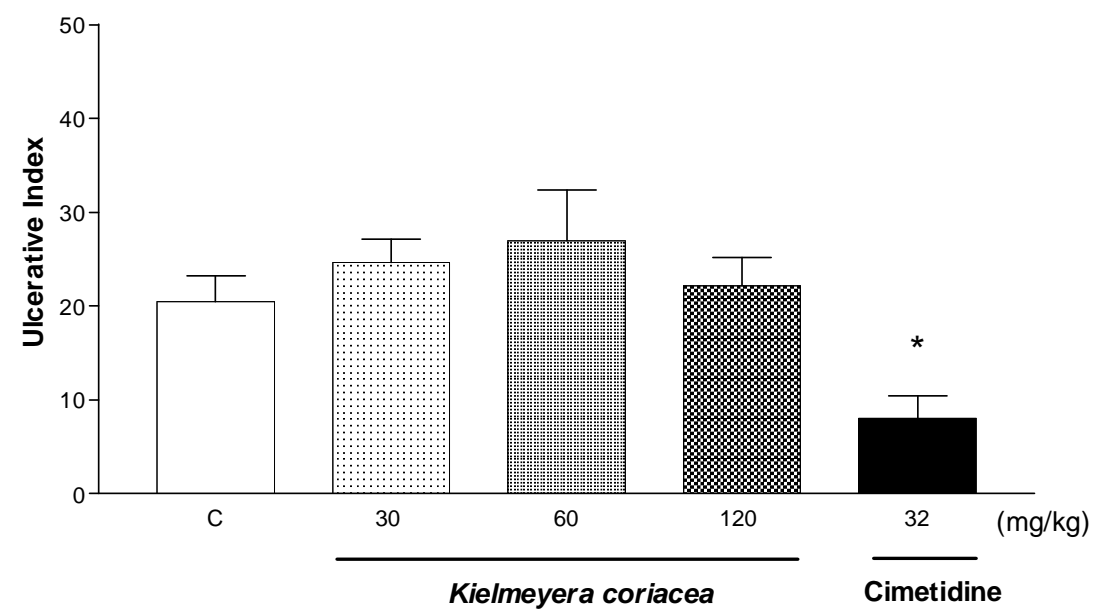

Figure 1 - Mean \pm SEM of ulcerative index obtained with oral doses of 30,60 and $120 \mathrm{mg} / \mathrm{kg}$ of hydroethanolic extract of Kielmeyera coriacea, control (C, $0.9 \% \mathrm{NaCl})$ and cimetidine $(32 \mathrm{mg} / \mathrm{kg}$ ) induced by stress model. ANOVA and Dunnet's test were utilized for comparisions, $(* \mathrm{p}<0.05),(\mathrm{n}=6)$.

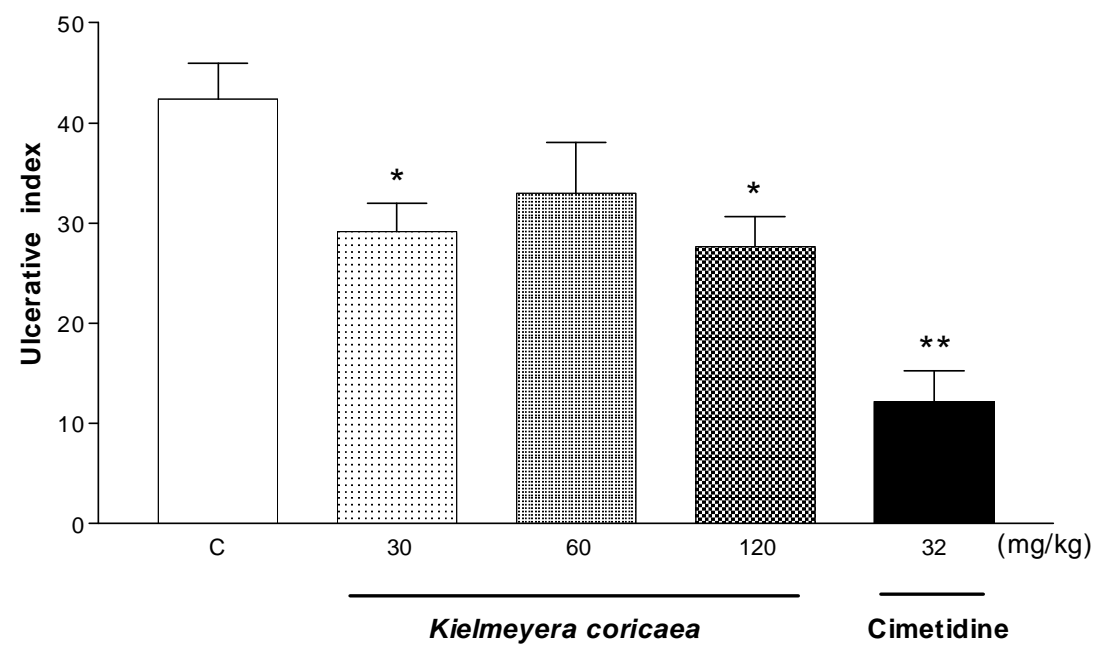

Figure 2 - Mean \pm SEM of ulcerative index obtained with hydroethanolic extract of Kielmeyera coriacea $(30,60$ and $120 \mathrm{mg} / \mathrm{kg}$, p.o.), control (C, $0.9 \% \mathrm{NaCl})$ and cimetidine $(32 \mathrm{mg} / \mathrm{kg})$ on ethanol-acid model. ANOVA and Dunnett's test were utilized for comparisions, $(* \mathrm{p}<0.05, * * \mathrm{p}<0.01),(\mathrm{n}=6-8)$. 


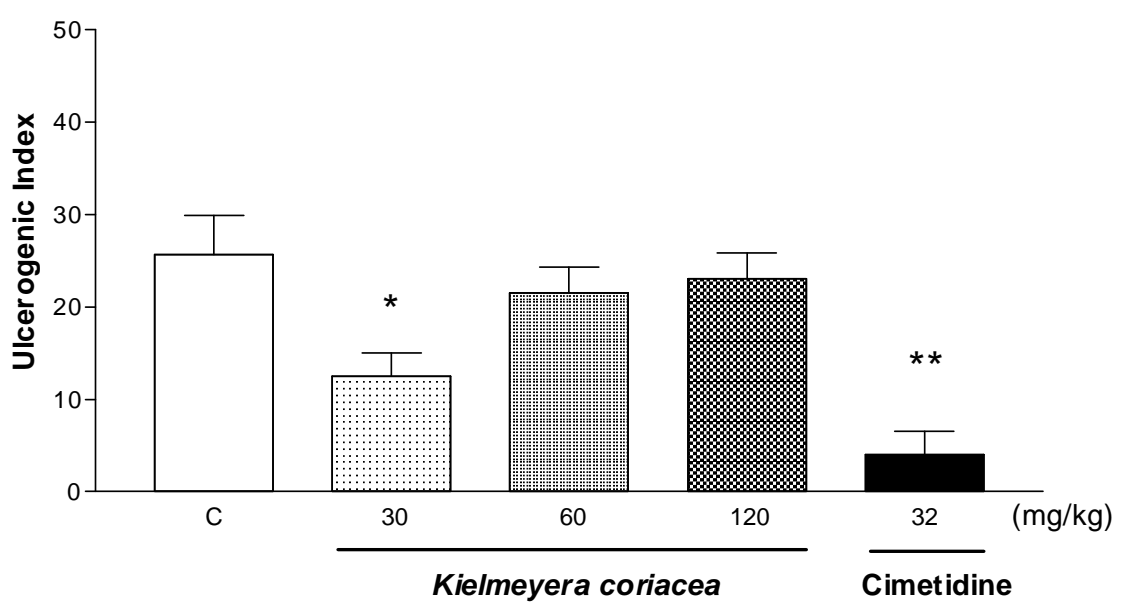

Figure 3 - Mean \pm SEM of ulcerative index obtained with diferent doses of extract of Kielmeyera coriacea, control $(\mathrm{C}, 0.9 \% \mathrm{NaCl})$ and cimetidine $(32 \mathrm{mg} / \mathrm{kg})$ on indomethacin model. ANOVA and Dunnett's test were utilized for comparisions, $\left({ }^{*} \mathrm{p}<0.05,{ }^{*} \mathrm{p}<0.01\right),(\mathrm{n}=6)$.

\section{DISCUSSION}

This study revealed a significant anti-ulcer effect of a hydro-ethanolic extract from $K$ coriacea in experimental models of gastric lesion induced by ethanol-acid and by a non-steroidal, antiinflammatory drug, Indometacin. Under our experimental conditions, different extract doses did not alter the gastric mucosal lesions in the stress model compared to the control.

Anti-inflammatory drugs like Indomethacin administered in toxic doses $(20 \mathrm{mg} / \mathrm{kg})$, produce visible gastric ulcers in animals. Indomethacin is a potent inhibitor of prostaglandin biosynthesis (Vane, 1971). Prostaglandins are known to play an important role in maintaining mucosal integrity. An Increase in certain endogenous prostaglandins can enhance gastric mucosal resistance to ulcerogenic agents (Robert, 1979). The mechanisms involved in prostaglandin action are multiple, including stimulation of mucus and bicarbonate output (Hogan et al., 1994), gastric mucosal blood flow (Gaskil et al, 1982), decreasing gastric motility, increasing the release of endogenous mediators of gastric injuryvasoactive amines and leucotrienes and stimulation of cellular growth and repair (Hawkey and Rantim, 1985). In the present study, the effect of the extract on prostaglandin biosynthesis was not evaluated, but an increase in resistance to the necrotizing effect of Indomethacin was noted. Ethanol-acid causes more severe gastric mucosal ulceration. The ulcers are caused either by a direct effect of the ethanol-acid solution on the gastric epithelium, or are modulated indirectly by the release of vasoactive products from mast cells (Szabo, 1987), resulting in the release of mediators such as histamine (Oates and Hakkinen, 1988).

Endogenous histamine formation and its release from mast cells in the gastric mucosa also have been implicated in the pathogenesis of gastric ulcers produced by acute stress (Guth and Hall, 1960). Levine and Senay (1968) showed that stress increases histidine decarboxylase activity in the gastric mucosa, and that the degree of increase correlated positively with the number and severity of lesions. Yet, it has been shown vascular changes in ethanol-induced gastric mucosal injury and severe damage in such injury is associated with extensive lesions of mucosal capillaries, increased vascular permeability and reduction of blood flow in mucosa (Gaskil et al, 1982). In our experiments, the extract prevented acute, gastric mucosal injury induced by ethanol-acid and indomethacin. In the ethanol-acid method, the protective action was produced at a lowest and at a highest dose, but not a intermediate dose of extract. The specific mechanisms underlying this action in unknown. However, as a first step, the extract should be fractioned and further studied. The extract did show a significant, cytoprotective effect against the gastric lesions induced by necrotizing agents, which suggests a direct, protective effect on the gastric mucosa. In contrast, 
the extract did not decrease the ulcerative index in the stress model at any dose used.

The mechanisms underlying the protective action of the extract against ethanol and indomethacin induced gastric lesions are unclear. Further studies using more specific methods are required to explore the compounds responsible for the protective effect, and the mechanism of this activity. Chronic toxicity studies are also in progress.

\section{ACKNOWLEDGEMENTS}

We thank M. A. Trombelli and J. A. Dantas for technical assistance. This study was partially, supported by CNPq.

\section{RESUMO}

A atividade antiulcerogênica do extrato hidroetanólico de caule de Kielmeyera coriacea Mart. (Guttiferae) foi avaliada em ratos por meio de três modelos experimentais: etanol-ácido, indometacina e estresse agudo. $\mathrm{O}$ índice ulcerativo observado após o tratamento com o extrato de Kielmeyera coriacea foi comparado com a droga de referência, cimetidina. O tratamento com o extrato mostrou significante atividade antiulcerogênica nos modelos de indução de lesões de mucosa gástrica produzidas por etanol-ácido e indometacina, mas não contra úlcera induzida pelo modelo de estresse agudo. Etanol-ácido e agentes antiinflamatórios, como a indometacina, são compostos que produzem úlcera de mucosa gástrica. Os resultados deste estudo sugerem uma atividade protetora de mucosa gástrica para o extrato de Kielmeyera coriacea

\section{REFERENCES}

Alves, T. M. A.; Silva, A. F.; Brandão, M.; Grandi, S. M.; Smânia, E. F.; Smania, J. R. A.; Zani, C. L. (2000), Biological screening of Brazilian medicinal plants. Mem. Inst. Oswaldo Cruz, 95, 367-373.

Aguwa, C. N. and Mittal, G. C. (1981), Study of antiulcer activity of aqueous extract of leaves of Pyrenacantha standtii (Family I cacinaceae) using various models of experimental gastric ulcer in rats. Eur. J. Pharmacol., 74, 215-219.
Audi, E. A.; Otobone, F.; Martins, J. V. C. and Cortes, D. A. G. (2002), Preliminary evaluation of Kielmeyera coriacea leaves extract on central nervous system. Fitoter., 73, 517-519.

Bacchi, E. M. (1988), Estudo farmacológico da ação antiúlcera dos extratos de Styrox camporum Pohl e Caesalpina ferrea martius. PhD Thesis: Instituto de Ciências Biomédicas da São Paulo University.

Cortez, D. A. G.; Young, M. C. M.; Marston, A.; Wolfender, L. and Hostettmann, K. (1998), Xanthones, Triterpenes and a Biphenyl from Kielmeyera coriacea, Phytochem., 47 : (7), 1367-1374.

Ferri, M. G. (1969), Plantas do Brasil: espécie do cerrado. São Paulo : Edgard Bluchar.

Gaskil, D. L.; Serinek, K. L. and Levine, V. A. (1982), Effect of prostacyclin on mucosal blood flow. Surgery, 92, 220-224.

Guth, P. H. and Hall, P. (1960), Microcirculatotory and mast cell change in restraint - induced gastric ulcer. Gastroenter., 50, 562-569.

Hawkey, C. J. and Rantim, D. S. (1985), Prostaglandin and gastrointestinal mucosa. Are they important in this function disease or treatment. Gastroenter, 89, 1162-1165.

Hogan, D. L.; Ainsworth, M. A. and Ibensberg, J. I. (1994), Gastro duodenal bicarbonate secretion eliminate. Pharmacol. and Ther., 8, 475-479.

Levine, R. J. and Senay, E. C. (1968), Histamine in the pathogenesis of stress ulcers in the rat. Amer. J. Psysiol., 214 : (4), 892-896.

Miller, L. C. and Tainter, M. L.(1944), Estimations of the $\mathrm{DE}_{50}$ and its error by means of log-probhit graphic. Paper. Proc. Soc. Rep. Biol. Med., 57, 261-264.

Mizui, T. and Douteuchi, M. (1983), Effect of polyamines on acidified ethanol induced gastric lesions in rats. Jpn. J. Pharmacol., 33, 939-945.

Nagura, M. (1972), Effect of psychotropic drugs on cathecolamines in brain and adrenal medulla of rats under stress producing peptic ulcers. Jpn. J. Pharmacol., 22, 545-549.

Oates, P. J. and Hakkinen, J. P. (1988), Studies on the mechanism of ethanol-induced gastric damage in rats. Gastroenter, 94, 10-21.

Robert, A. (1979), Cytoprotection by prostaglandins. Gastroenter, 77, 761-762.

Szabo, S. (1987), Mechanisms of mucosal injury in the stomach and duodenum: Time-sequence analysis of morphologic, functional, biochemical and histochemical studies. Scan. J. Gastroent, 22 : (127), 21-28. 
Szelenyl, I. and Thiemer K. (1978), Distention ulcer as a model for testing of drugs for ulcerogenic side effects. Arch. Toxicol., 41, 99-105.

Vane, J. R. (1971), Inhibition of prostaglandin synthesis as a mechanism of action for aspirine-like drus. Nature (New Biol.), 231, 232-235.

Received: September 04, 2003; Revised: May 13, 2004 Accepted: November 24, 2004. 